
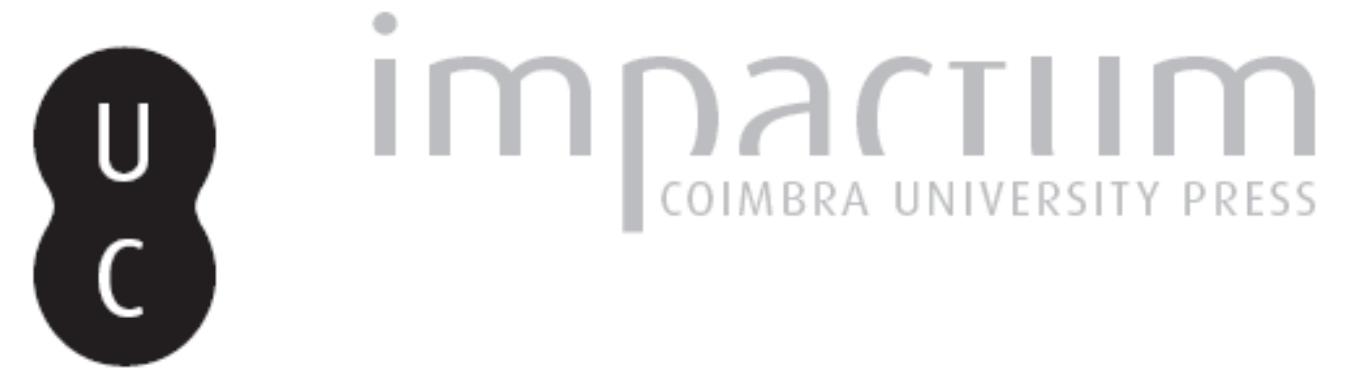

\title{
Public housing in fascist Rome: a European perspective
}

Autor(es): Bodenschatz, Harald

Publicado por: Editorial do Departamento de Arquitetura

URL persistente:

URI:http://hdl.handle.net/10316.2/43463

DOI:

DOI:https://doi.org/10.14195/1647-8681_8_6

Accessed : $\quad$ 26-Apr-2023 15:59:13

A navegação consulta e descarregamento dos títulos inseridos nas Bibliotecas Digitais UC Digitalis, UC Pombalina e UC Impactum, pressupõem a aceitação plena e sem reservas dos Termos e Condições de Uso destas Bibliotecas Digitais, disponíveis em https://digitalis.uc.pt/pt-pt/termos.

Conforme exposto nos referidos Termos e Condições de Uso, o descarregamento de títulos de acesso restrito requer uma licença válida de autorização devendo o utilizador aceder ao(s) documento(s) a partir de um endereço de IP da instituição detentora da supramencionada licença.

Ao utilizador é apenas permitido o descarregamento para uso pessoal, pelo que o emprego do(s) título(s) descarregado(s) para outro fim, designadamente comercial, carece de autorização do respetivo autor ou editor da obra.

Na medida em que todas as obras da UC Digitalis se encontram protegidas pelo Código do Direito de Autor e Direitos Conexos e demais legislação aplicável, toda a cópia, parcial ou total, deste documento, nos casos em que é legalmente admitida, deverá conter ou fazer-se acompanhar por este aviso.

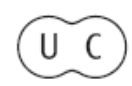


Harald Bodenschatz

Public I-Iousing in Fascist Rome A European Perspective

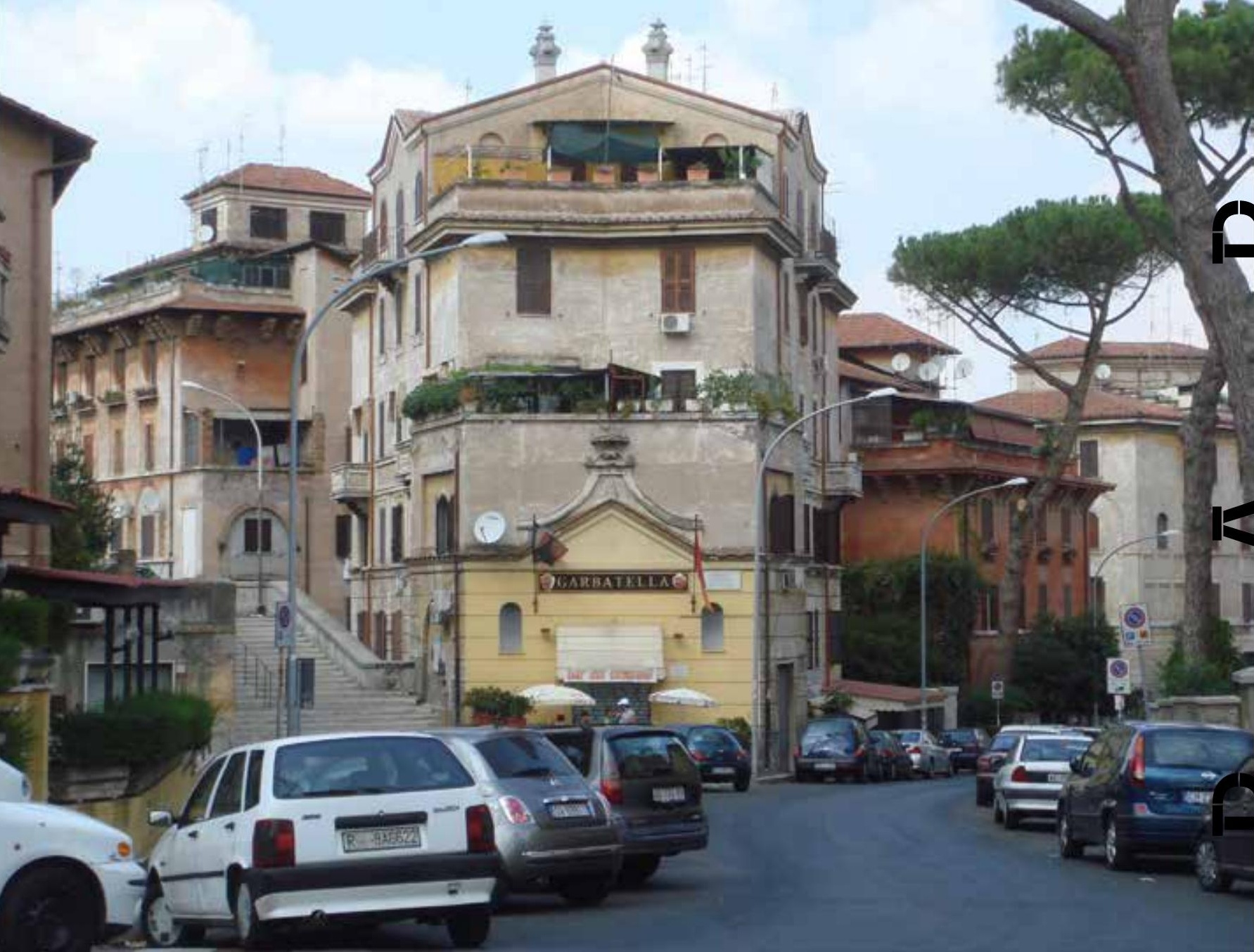


Today, publicly subsidized housing development in the Europe of the interwar period is largely met with broad appreciation. This appreciation stems from the social orientation of the housing programme as well as its urban design and architectural form. Actually, some of these housing projects have been ranked as World Heritage Sites - such as Berlin's 1920s modernist estates. Studying the historiography of architecture, one is likely to think that such estates were typical of the interwar period. In fact, it is implicit that these estates were planned for the working poor. Conversely, it is assumed that dictatorships of that time were woefully neglecting public housing programmes in order to build large monumental buildings. The little public housing that may have taken place in those countries is equally considered to be of poor quality and therefore not worth of further research. There are thus no comprehensive studies on public housing in Berlin during the Nazi regime, and the larger part of students still think that there was hardly any public housing being built at all. This phenomenon underscores an overly simplified understanding of dictatorships, which ignores that these regimes were sustained by the endorsement of parts of the population, by "consensus" as the Italians would put it.

It is my assumption that public housing was key in securing the consensus of the supporting middle classes for dictatorial regimes. It is therefore imperative to look at public housing not only from an architectural or urban design point of view but as well in terms of its social addressees. Public housing for whom? Putting it more complexly: which architectural and urban design forms in what location were offered to the various social classes by a given dictatorial regime? Maybe the answer to this question is not surprising. However, it is surprising that this issue is hardly ever debated ${ }^{1}$. This article introduces the most important public housing programme in a dictatorship during the first half of the $2 \mathrm{O}^{\text {th }}$ Century in Europe, the public housing in fascist Italy illustrated by the example of Rome. For it is in the capitals that the societal project of each dictatorship is represented in its clearest form ${ }^{2}$.

\section{Publicly subsidized housing in Mussolini's Rome}

Just as in other European cities, the question of housing became paramount in Rome in the aftermath of World War I. During and after the war, housing conditions deteriorated in the Eternal City, too. The number of slum dwellings clearly underlines the dire housing shortage. An estimated 45,000 to 100,000 people lived in slums or in very basic housing in the wake of World War I.

\subsection{Agencies of publicly subsidized housing in Rome: ICP, INCIS and private companies}

The Mussolini regime, as well as other European nations, focused on large public housing companies. Founded in 1903, the Istituto per le Case Popolari (Institute for Subsidized Housing, ICP), oversaw the
Frontispiece Public housing in Garbatella (built by the Istituto per le Case Populari during the 1920s). Photograph: Harald Bodenschatz, 2009. 
centralization of various institutions and during the 1920 s undertook a vast array of activities. In 1923, it was consolidated and brought under fascist control. In terms of class, it was not only providing for the working and the sub-proletarian classes with housing, but the middle classes as well, especially between 1923 and 1930. In the second half of the 1920s, the ICP produced some 1000 apartments per year and in 1927 it reached 2000 apartments. In 1930, out of Rome's 900,000 inhabitants more than 60,000 lived in apartments provided by the ICP. The housing development for middle classes carried out by ICP was deprived of its foundation when, in 1928, the private sector started to be subsidized. Thus, at the end of the 1920s, the ICP focused on providing housing for the poor, for immigrants, for slum dwellers, for the homeless and for other marginalized populations.

Established in 1924, the Roman Istituto Nazionale per le Case degli Impiegati dello Stato (Institute for Housing Development for Government Employees, INCIS) was intended to represent a model institution of fascist efficiency and economy. Its aim was to build apartments so as to ensure the desired mobility for government employees. It favoured highly valued central sites with an urban character and an architecture which was supposed to mirror local architectural traditions. The INCIS was technically a national institution, but Rome was clearly its main focus. The programme for the capital included 1500 new apartments which made up for 37 per cent of its national programme. In the years between 1924 and 1939, the Istituto built 4941 apartments in Rome and 11,209 throughout Italy (including Rome).

Housing policy during the Mussolini regime was not coherent. In 1923, a couple of drastic but contradictory measures were decided: the partial elimination of rent control, tax exemptions for 25 years for new buildings and the elimination of a tax on development sites. Subsequently, housing development, which had been stagnant in the post-war years recovered, just to decline again in 1925. It took another reversal of housing policy to jump start housing development in 1929 to 1930. Private development companies that until then had mainly built apartments for high-income households were then subsidized under certain conditions. Their new product, the Case convenzionate, a type of apartment built within the framework of contracts with the public sector, was introduced in 1928. Through this new product, private housing development was privileged at the expense of the ICP. At the same time, the addressees changed. Instead of "poor families", who were still provided for by the ICP, it was now "families living in modest circumstances" those who were subsidized.

The development of the Case convenzionate was subsidized at the rate of 100 Lire per living unit under the following conditions: rent had to be restricted to a certain amount; that level had to be sustained for at least 5 years; the public sector had to be guaranteed a right of occupancy. This measure was intended to buffer the planned elimination of rent control for 1930. Owing to the fact that 
the municipality provided technical and transport infrastructure, the programme promoting high-density building proved attractive to private investors and it was thus relatively successful. These apartments benefited selected social groups, especially the lower ranks of the middle classes that disposed of regular income. This was a group cherished by the regime morally as well as politically. In fact, victims of war and of the so called "fascist revolution", families with many children, medalled soldiers, retired employees of the Roman municipality and those evicted from their apartments by no fault of their own were among the favoured for these new apartments.

The decisive turnaround in Roman housing development occurred at the end of the 1920s when the private sector ousted public development companies due to the distribution of state subsidies. Since then, large companies such as the Società Generale Immobiliare, the Impresa Federici, the Istituto Nazionale Immobiliare and the Istituto Nazionale Assicurazioni (INA) were key players in developing both private and publicly subsidized housing.

\subsection{Urban design types of publicly subsidized housing in Rome}

Publicly subsidized housing development in Rome can be differentiated into four main urban design types: firstly, the garden suburb that is situated outside city expansion areas and built by public development companies. This type was used only during a short period in early 1920s, to build a housing development for working and middle classes. Secondly, the compact urban quarter built within city expansion areas, developed by public companies, which dominated the second half of the 1920s. This was a housing development primarily intended for the middle classes. Thirdly, the borgata, a basic settlement developed by public companies far away from the city, which became significant in the late 1920s and was built until the end of the dictatorship. This was a development aiming marginalized, unemployed, homeless, subproletarian classes, in short, classes who were not welcome in the capital. Finally, the insular, high-density estate that was developed by private companies within the city expansion areas, a typical product of the 1930s, a type of housing development meant for the lower middle classes.

\subsubsection{Garden suburbs}

At the beginning of the 1920s, Roman housing policy followed the emerging European trend to disperse populations according to the garden suburb concept. Two significant examples of the short-lived decentralization policy are the Garbatella and the Aniene garden suburbs, initiated in 1920.

The "garden-borgata" Garbatella is the most commonly known housing estate of the Istituto per le Case Popolari (ICP). Completely isolated, it was built near the basilica of S. Paolo fuori le Mura and in the vicinity of a potential development axis, the Via Ostiense, leading 
Fig. 1 Public housing in Garbatella (built by the Istituto per le Case Popolari, 1926-1928). Photograph: Harald Bodenschatz, 2009. from Rome to Ostia on the coast. Along this axis, an industrial zone included a gasometer and the central market. The social addressees of this garden suburb were the poorer classes. The development of Garbatella did not occur according to one coherent plan, but was rather the result of several partial plans.

The first sections, built from 1920 to 1922, covered only a tenth of Garbatella and only this section was built according to the garden suburb design principles. It is the housing estate with the lowest density of any ICP estate in Rome. The development comprised of a suburban quarter with 204 apartments arranged around a small central square, the Piazza Benedetto Brin. The square was connected to the broad radial road Via Ostiense by a flight of stairs at the end of which the main building rises in a theatrical manner. The Piazza Benedetto Brin itself is composed as a small centre with a slightly higher degree of density and mirrors the popular local architectural style of the barocchetto.

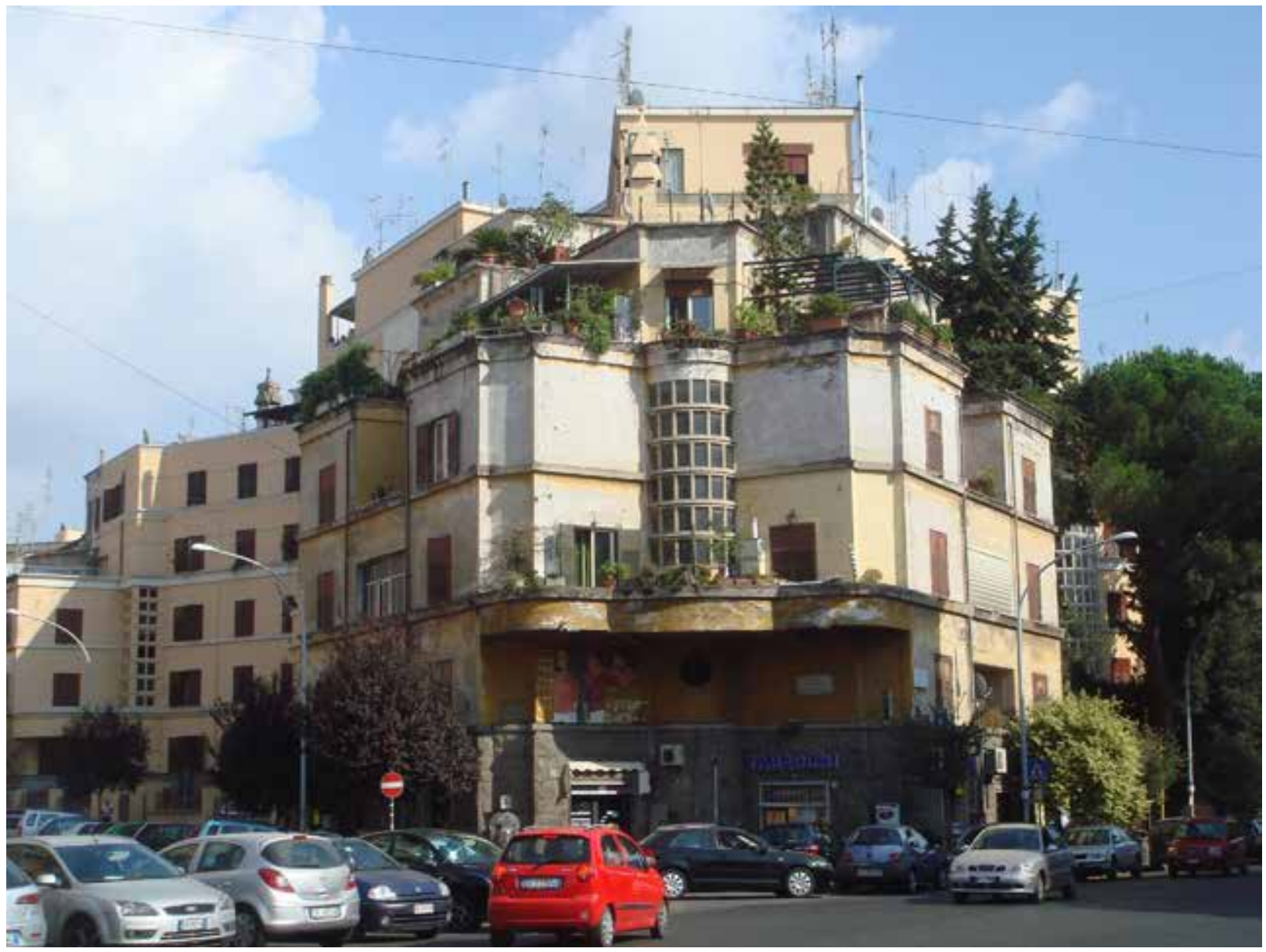


Since 1923 the housing estates developed by ICP would become gradually denser. At the Piazza Bartolomeo Romano two remarkable public buildings were erected, the Bagni Pubblici and the CinemaTeatro, designed by Innocenzo Sabbatini, the most important architect of public housing in Rome. Both complexes reference ancient Roman archetypes in terms of their architectural style. These two buildings dominate the Piazza Bartolomeo Romano and form a second centre for the neighbourhood. From 1926 to 1928, the famous four alberghi suburbani with 997 living units and communal sanitary facilities were built by Sabbatini and were intended for those affected by demolitions. These alberghi were grouped around a third centre, the Piazza Michele da Carbonara, and represent a peculiar type of public housing development. They were originally intended only as temporary accommodation, but due to housing shortage were repurposed for longterm accommodation. The ground floor levels were occupied by service facilities such as police station, kitchens, dining halls, kindergartens, and emergency rooms. Later, playgrounds and a cinema were added to integrate leisure into the communities. The Piazza Damino Sauli ultimately became a fourth centre where the monumental Michele Bianchi School (1929-1930) and the San Francesco Saverio church (19311933) were erected.

At the beginning of the 1930s, the development of the "gardenborgata" which was entirely built by the ICP came to its end. The development of this suburb had the mark of many architects and thus displayed a vast artistic scope. This is why Garbatella is often called the "drill ground of housing development". This formerly isolated garden suburb encompasses indeed an extraordinary diversity in urban design and architecture that is rarely found outside historically grown quarters. This is where it differs greatly from settlements in Germany or elsewhere. Even today, the exceptional social and urban character of Garbatella can be experienced.

Within the framework of the Consorzio Città Giardino Aniene, established in 1919, the Istituto per le Case Popolari (ICP) in cooperation with another company developed the "English-type garden city" Aniene, on 150 hectares in the Northeast of Rome at Monte Sacro. The addressees of Aniene were more privileged classes than those in Garbatella. The plan comprised 500 small houses with two to three storeys and a garden, structured along the bend streets typical of garden suburbs. There were also numerous areas for sports and green space as well as an archaeological park. The garden suburb of Aniene had a small and picturesque centre, the denser Pizza Sempione with a church, some palazzi, a school, post office, cinema, shops and a small park. The suburb was well connected to the rest of the city by a new bridge and several tram lines that ran over the Via Nomentana. 


\subsubsection{Urban housing complexes}

The decentralization policy that aimed at establishing garden suburbs was soon abandoned and later, due to its low density, harshly criticized as being wasteful and monotonous. As the garden suburb concept was no longer supported, public housing development in Rome concentrated on compact urban estates built in blocks. This was the most important type of public housing development in Rome, a type that had already influenced the latest part of the development in the Garbatella garden borgata. Estates of this type were of varying size: they could comprise part of a block, an entire block or even shape a whole quarter. And they were primarily informed by regional architectural styles. The block itself was built in a varying form, in contrast to housing developments before World War I. It was not completely closed and had generous and beautiful green spaces within. The estates addressed the working poor and the new middle classes, aiming the patronizing integration of these classes into the city. The housing estates were therefore well integrated into the urban context, as they did not stand out from other products of private housing development.

Besides the two garden cities, the ICP developed a series of larger estates in the urban context, in the second half of the 1920s, which the Tiburtino II estate is an example. The Tiburtino II quarter stretched between the Piazza Bologna and the Stazione Tiburtina in the east part of the city. Its 667 dwelling units, mostly smaller public apartments, were built in a hilly area, according to the plan designed by Ignazio Guidi and Innocenzo Sabbatini. Built at lower density, the quarter spread across a traditional layout with hierarchically ordered squares, streets and paths, but abstained from a schematic perimeter block development. By varying the building types and adding several special building types, it created an impression of diversity, which was further accentuated by the landscaping of the complex. There is a striking richness of public and semi-public spaces, whose centre is the Piazza Pontida. A distinctive entrance situation and landmark buildings emphasize the relative closeness of the area. Tiburtino II is a great reference of an urban design concept that matches its context.

West of the neighbourhood, there is a famous housing estate, the casa a gradoni, with 89 public apartments and shops on the ground floor. This high-density estate with up to seven storeys was built in 1929 and 1930 on a triangular plot by the ICP following the plans designed by Innocenzo Sabbatini. The so-called "stair house" gets its particular form from its stepped terraces that cover a narrow and bent yard.

The Savoia neighbourhood, near Piazza Verbano, is a reference of the housing complexes developed by the Istituto Nazionale per el Case degli Impiegati dello Stato (INCIS). It was planned by the engineer Dario Barbieri for a site in the northeast of Rome. It was developed between 1925 and 1931, and it is one of the largest contiguous housing 


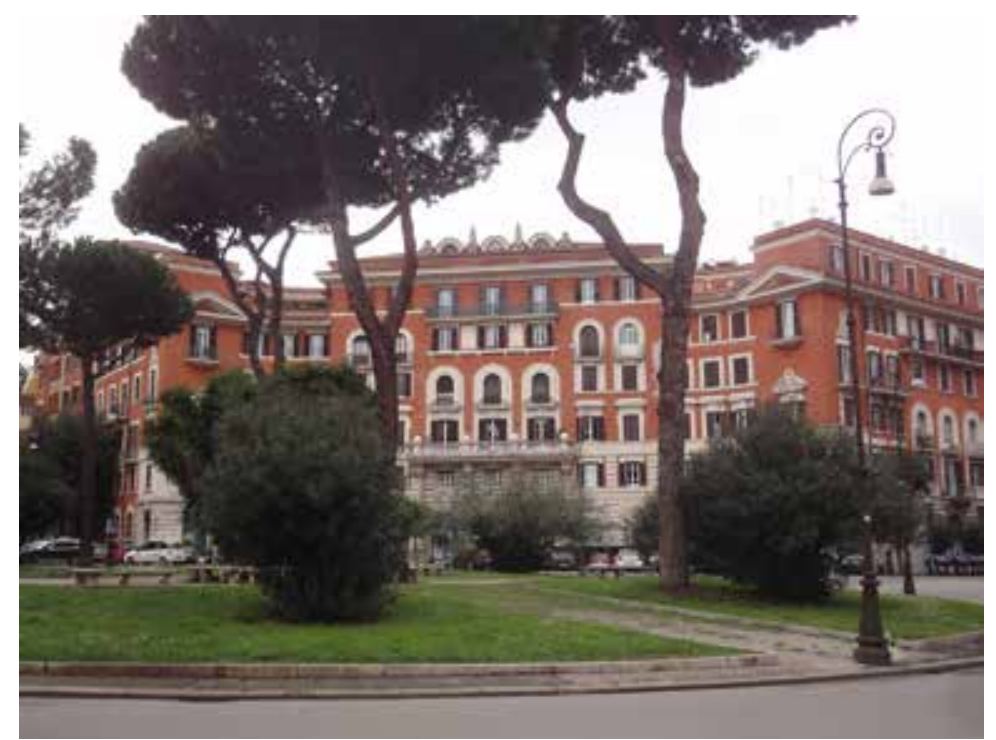

estates of the 1920s, accommodating 2,000 apartments for 10,000 inhabitants. To build it an existing settlement, the Villa Lancelotti, had to be dissolved. Planned for government employees, this housing estate differs greatly from those developed by ICP. It is even more urban and embedded into the city expansion as planned in the master plan of 1909. Its streets are lined by trees and defined according to an hierarchical structure. The main road includes the tram line, shops, restaurants and other facilities. The octagonal Piazza Verbano, designed in 1930 by Raffaele De Vico defines the natural centre of the quarter. Within or at the edge of the estate there were a cinema, a church, a post office, a school and a city park, the Parco Virgiliano, also designed by Raffaele De Vico, who was the most important landscape architect of the Mussolini era in Rome.

The quarter surrounding Piazza Verbano was not comprised of simple perimeter blocks, but rather of a variety of buildings with large planted yards with playgrounds. The six to seven storey buildings are decorated in a traditional style. Parts of the quarter show a modernist architectural style but follow the traditional street layout.

\subsubsection{Borgate}

The inner city projects of the public housing development were not sufficient to house the many immigrants from rural areas and the poorer inhabitants of the old town who were affected by the isolation of antique Roman monuments or by the construction of new avenues. As it became obvious that the demand for housing could not be met with current policies, the development of housing estates outside the city expansion areas was reintroduced. These new settlements were called borgate. But this new form of decentralization, promoted the marginalization of unwanted populations, instead of their social cohesion.
Fig. 2 Public housing at Piazza Verbano, quarter Savoia (built by the Istituto Nazionale per le Case degli Impiegati dello Stato, 1925-1931). 
Due to their location, far away from the city and their poor transport connections, the borgate were totally isolated, in contrast to the inner-city projects. They were neither connected to the city nor to their surrounding countryside. The buildings were manufactured using inferior materials and in many cases had no running water and no toilets. In order to maintain the "security" of the housing complexes, police stations were installed in many borgate. As the housing shortage continued during the fascist regime, despite the poor sanitary and social conditions these borgate, once planned as temporary accommodation, became permanent housing. Aside from these official borgate planned by the regime, illegal and unplanned borgate were also created and had to be legalized subsequently. Legal and illegal basic settlements are not limited to the era of the Fascist regime but are part of Rome's modern development history, even today.

In spite of their infamous reputation among the Italian public, there is still little knowledge on the history of the borgate. Derived from "borgo", a word that describes a small inner-city quarter or a small rural village, the term "borgata" carried the rather negative connotation of an unfinished settlement. This is what the borgate actually turned out to be. These planned basic settlements were developed to accommodate the urban poor that were no longer given the right to live in the city, those who were evicted to give way to the renovation of Rome's centre as a showcase for the fascist regime. This represents a drastic turn in housing policy: unwanted or unpopular populations were supposed to be moved out of the city and into the regional "backyard".

The introduction of the borgate was a direct consequence of the change in housing policy favouring private development companies and the factual ousting of the Istituto per le Case Popolari. The Roman municipality aimed at radically lowering building costs by using cheap materials, inferior standards in technical equipment and social facilities and lower land prices which were only available far out of Rome. The switch to building cheap and simple housing gave rise to unprecedented social segregation and the de-urbanization of the poorest.

The borgate accommodated not only victims of demolitions in the city centre. The borgate collected a diverse social mix: the poor, victims of the abandonment of rent control, inhabitants of illegal settlements, poor migrants from rural areas ("rural exodus"), unemployed or partially employed, and those who returned from the Italian colonies in Africa, among many others. The living conditions were not homogenous as it is often reported. In fact, the allocation of the apartments, the provision of social facilities, construction materials as well as building types differed greatly as did the connection to the city by public transportation. Whereas some borgate looked like camps, some showed particular layouts with remarkable production of space within their urban design. Due to their remote location, the borgate functioned as catalysts for urban sprawl. As private development companies were able to use their 
infrastructure - albeit a poor infrastructure -, the borgate enabled those companies to develop the area between them and the city in a profitable way. This effect was calculated by the Roman municipality hopping to demolish the borgate and sell the land once its price had risen. In this respect, the borgate were a temporary fix and not a final solution.

While the decisions to build the borgate were made in 1929, the first generation of these basic settlements was not built until the first half of the 1930s. They were directed and built by the Roman municipality, and not by the ICP. A reference of this meagre generation was the borgata Gordiani in the east of Rome. The buildings of the borgata were one storey barracks without toilets. A record of a contemporary parliamentary investigative committee into poverty in cities describes the borgata as follows:

The buildings are neither equipped with running water nor toilets. Wells (that serve as washing facilities as well) and toilets are rare in the area, and to a certain number of flats is allocated one such facility. The doors of the flats connect directly onto the streets [...]. Built in extreme haste and with little resources, the buildings are run-down by use and deterioration, roofs are leaking and due to the lack of maintenance water seeps into the rooms below and soaks everything - household items, linens,... There are no trees, no grass ... Only the main road is paved... every now and then there are concrete boxes along the side roads: 25 toilets for 5000 people. They are open on all sides without doors or only so much as a thin screen. They are dirty beyond description as they belong to everyone and no one and are therefore rarely cleaned. The water pipes that provide the population with water are in direct vicinity to the latrines. Sometimes these pipes burst and water runs to the houses' doors. Equally unhygienic are the three public washing areas where the entire population does its laundry as there is no water in the houses. Streets - that is if one should call the narrow alleys between the barracks such - are not paved, are nothing but uneven ground, dusty in summer and muddy when it rains, covered in puddles and rills. The low and rectangular buildings are lined along these streets. The walls have two or three windows and one door. There is no market... no pharmacy, no post office, there is not even a butcher, though due to their poverty inhabitants do not regard this as a huge loss on their part ${ }^{3}$.

In 1935, the conditions of housing production in the borgate changed as the municipality of Rome underwent a change of power: the second generation of borgate was no longer built by the municipality but by ICP. Hence, the ICP regained its role as the main provider of housing for poorer classes, even though hopes for large-scale subsidized housing development programs were disappointed by the regime. 


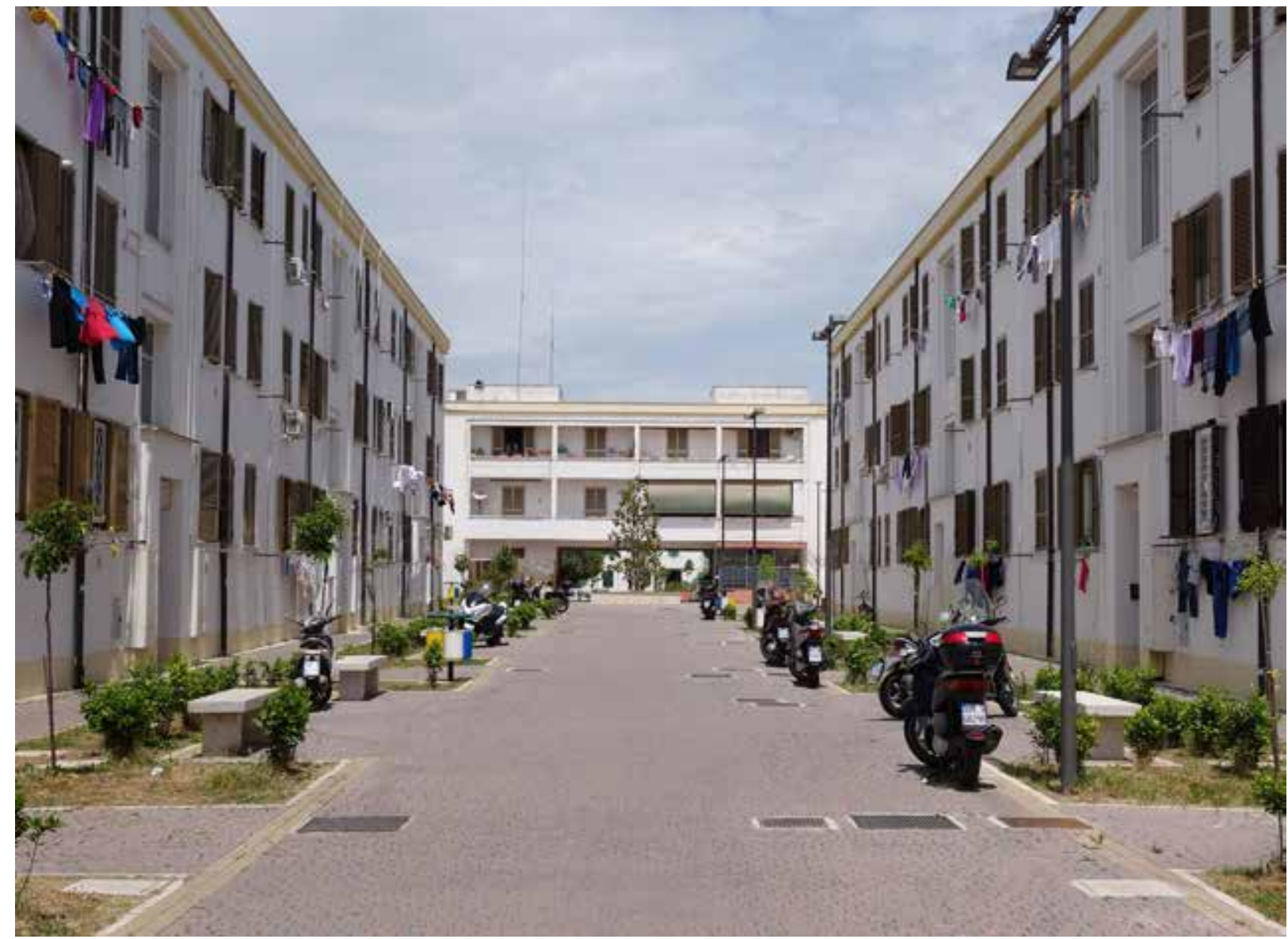

Fig. 3 Borgata Primavalle (built during the 1930s). Photograph: Harald Bodenschatz, 2015.
Between 1935 and the downfall of the regime in 1943, more borgate were built, among which are the Tiburtino III, Acilia and Quarticciolo. Some of the ICP's newer borgate were clearly different from the first generation borgate. Some areas were planned with more elaborate layouts and interesting space productions. Often, not always, what was built were "houses instead of barracks" with running water, toilets and communal facilities, which functioned poorly and were insufficient. From 1936 to 1937, the Tiburtino III borgata was constructed, according to a rationalist architecture designed by Giuseppe Nicolosi.

The urban structure is organised by a shifted axis, where the buildings of one to two storeys are oriented in north-south and east-west direction. Nevertheless, due to its meagre architecture, the estate offered little in terms of public space. Acilia was installed to the south of the capital, between Rome and Ostia, in a malaria infested area. Its urban design, with no central area, as well as its building types, was very simple and made it seem like a camp. Built from 1940 to 1943, the Quarticciolo borgata, designed by Roberto Nicolini, director of the design department at the ICP, is one of the best borgate. Thanks to its diverse building types and rather complex production of space with numerous squares and open spaces, the usual monotony of the borgate was overcome. 
Already in the 1930s, the borgate became object of fierce criticism. Innocenzo Costantini, director of the ICP, described them at the "V. Congresso Nazionale di Studi Romani" in 1938, as unworthy, counterproductive to the most elementary principles of hygiene and moral, as a waste of money and centres for hazards of all kinds, as places that actually degrade the price of land in their area instead of elevating it.

\subsubsection{High-density housing estates}

Against the backdrop of a dramatic aggravation of the housing shortage, the early 1930s were years of partially extreme increases in density for inner-city projects. As a result, large and monotonous complexes were built as high-density islands housing a magnitude of functions, including sometimes cultural facilities. These complexes were often developed by private companies as part of the subsidized Case convenzionate. The abandoned traditional architectural style had been replaced by often simple, very strict and undecorated variations of modernist architecture.

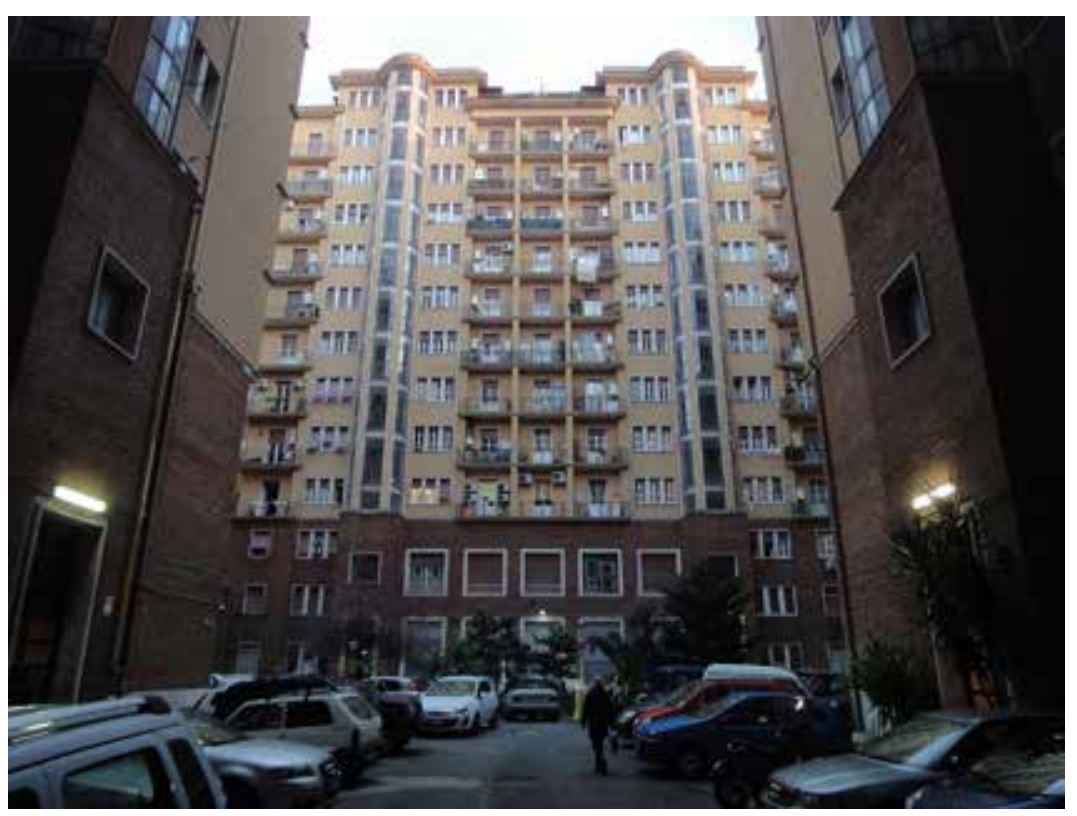

The most striking and probably the largest example of one such high-density block can be found at the Piazza Bologna, near the Villa Massimo: the Palazzi Federici. Its promoter was the Impresa Federici and it represents publicly subsidized private housing development, the so-called edilizia convenzionata. Built from 1931 to 1937 , on a nearly rectangular plot of 15,400 square meters, included 442 apartments that were developed surrounding two larger connected yards as planned by Mario De Renzi. The ground floor level, housing 70 shops and a
Fig. 04 Palazzi Federici near Piazza Bologna (built by the Impresa Federici, 1931-1937). Photograph: Harald Bodenschatz, 2013. 
cinema, was repurposed in 1968 to become a supermarket. The height of the "futurist" complex varies depending on the location, the main façade along the main street is distinctively higher than those facing the side streets. This way, the housing colossus reveals the intention to fit into its context.

In the first half of the 1930s, another two such large high-density blocks with smaller apartments were developed by the ICP. These were the Donna Olimpia complex in the southwest of Trastevere (Monteverde) and the Val Melaina complex in the northwest of Rome. Donna Olimpia was built from 1930 to 1932 in an isolated location and formed a large undecorated and strict housing block. Called "skyscrapers" (Grattacieli) by their inhabitants, the buildings dominated a square, the Piazza Donna Olimpia. This housing complex underscored an important architectural principle of the public housing development of the 1930s: an unprecedented austere simplicity in the housing development for the middle classes. The location of the Val Melaina complex, also developed from 1930 to 1932, was even more isolated. Its architectural design, however, was not as austere. In its compact layout, buildings were grouped around rather generous green yards. Inhabitants of these two ICP housing complexes were poor but did not belong to the very poor who had to live in the inferior borgate of the first generation.

\section{Perspective: Housing development and dictatorships in interwar Europe}

The output of Rome's housing policies was, as in other European countries, quite substantial. However, considering the city's immense housing shortage, it was utterly insufficient. In total, some 197,000 apartments were built from 1924 to 1930 . This is similar to the production of public housing during the so-called "Red Vienna", as it is emphasized by Italian researchers. In contrast to the German case, the Italy of the interwar period concentrated on urban and compact city expansion, as was usual before World War I, and not on decentralization in the form of settlements. The fascist regime aimed at and succeeded in implementing a remarkable societal concept: the urbanization of the supportive middle classes. The regime bound these classes by providing attractive housing in the form of compact city expansions. At the same time, city centres were modernized and the regime was able to offer employment in an attractive urban environment.

Thereby, a particularly Roman way of urban housing development in the 1920s was initiated, a project of the urbanization of the middle classes that is unique in its dimension. This was complemented by another particularity since the mid-1920s in Europe: the very early introduction of residential property. Italian public housing development of the 1920s is therefore a peculiar urban form of mass housing development regarding its social, economic, architectural and urban 
design aspects. It joins the ranks of the settlement development in Germany, the proletarian fortresses of "Red Vienna" and the suburbanization in the USA. This particular aspect of Roman housing development policy is, still today, little known outside of Italy. But other aspects of the fascist housing policy may not be overlooked. For example, the remotely located borgate were used to dispose of unwanted poor immigrants or those pushed out of the city centre. Therefore, de-urbanization in Italy actually means the segregation of the undesirable social classes out of the city.

The housing development during the Mussolini era in Rome is surely unrivalled in both dimension and variety, but is it truly unique? Looking at Portugal, it is not unique at all. In Lisbon too, during the dictatorship of António de Oliveira Salazar, public housing programmes were socially differentiated. The upper middle classes, just as in Italy, were offered large urban apartments in the city expansion areas, though built by private investors. For the middle classes with lesser incomes, nucleated, more isolated low-rise settlements were on offer and for the poor migrants from rural areas only isolated camp-like developments. Aside from those, there were illegal slums as there were in any larger city.

It is interesting to see that even the Soviet Union under Stalin did aim at the urbanization of its elites during the 1930s. Only in the early 1920s, the concept of garden suburbs was popular, like in Italy. Later on, housing palaces were built for the privileged social classes. The majority of the inhabitants had to live in apartments in older buildings that had to be shared with other households due to the housing shortage. The new cities of Siberia were even more segregated: there were mansionlike accommodations for foreign experts and top workers, some new buildings for skilled workers and accommodation in tents for unskilled workers, even worse accommodation for those in forced labour.

Looking at the housing development in Nazi Germany, one can quickly gather that there was no comparable socially differentiated public housing programme. The large and compact, semi-urban settlements in Berlin for example - still referencing the housing development typical of the Weimar Republic - aimed at the egalitarian mass development of housing. They addressed loyal German populations, though. The housing developments during the Nazi era in the larger cities remained strangely undefined in respect to their intended social addressees. They were orientated towards achieving the uniform city that was not attractive to privileged Germans. On the other hand, the suburban model settlements, built in the early 1930s, were strictly ordered, socially homogenous alternatives for the privileged middle classes.

There is however another form of Nazi housing policy that is often overlooked. Not just in Germany, but elsewhere, too. This kind of housing development was not represented in the publications of the 
propaganda bureau, and is still today seldom shown in architectural historiography. The Nazi new town of Wolfsburg, for example, was mostly a shantytown. The development of camps for forced labour was the last stage of Nazi housing development. Or the penultimate, if one were to consider the building of apartments for those made homeless by the bombs as the ultimate stage.

Regarding the camps for forced labour, they seem to underscore that one should make no connection between the housing policies of the Weimar Republic and Nazi Germany. But it should not be forgotten that the first generation of Nazi housing development was a continuation of housing development of the Weimar Republic: the so called settlements for the unemployed. These basic settlements were comparable to the borgate in Rome: very remote, promoting self-help, without bathrooms, running water, service or communal facilities and deprived of appropriate transportation connections to the city. A product of a de-urbanization policy, they had a clear addressee: unemployed workers. The legal foundation for this type of settlement that was established as an answer to the world economic crisis was an emergency decree of the Brüning government in 1931. After 1933, the program was continued by the Nazi regime. In Berlin, for example, the settlement of Marienfelde was built according to this program in 1932/33. This settlement was mostly composed of single-storey semidetached houses and complemented by some detached houses. In total, some 394 settler's holdings were established, which resulted in a uniform and regular townscape.

The settlements for the unemployed of the late Weimar Republic differed from the famous settlements of the 1920s in important aspects. They differed in their appointment and architectural form as well as their social addressees. But they also had common features, such as their contribution to promote the suburbanization of housing. They did aim at different goals, though. Many reformers and the housing policy of the era before the world economic crisis of the late 1920s dreamt of the suburbanized city region as exemplified in England. After the world economic crisis, housing policy - not only of dictatorships - led to the emerge of multiple examples of the city region with an urban core for the middle classes and isolated exurban islands of housing for unwanted inhabitants.

The new building code of the Weimar Republic did not allow the traditional courtyards and demanded lower density and the separation of functions. Due to these regulations the urban design changed radically as the compact and mix-use blocks were dropped so did the urban streets and places. Bit by bit, suburban living in the midst of green areas replaced the inner-city housing. The developers favoured by the new housing policy were non-profit organizations. Their new subsidized housing developments had narrowly defined the addressee: the new middle classes, especially white-collar workers. This relatively social homogeneity of the new housing types 
of the 1920s is often overlooked. This is however a critical point, the programme that resulted in this homogenous settlement landscape is based on the mistaken view that egalitarian buildings could result in more equality. In an unequal society such development does however promote something completely different: the large-scale segregation in a sprawling city region, segregation that was further promoted by the settlements for the unemployed.

In conclusion, these arguments can be characterized in four hypotheses. Firstly, dictatorships are not only based on terror, but on consensus as well. Housing development for the all-important middle classes was a decisive catalyst in order to secure consensus. Secondly, housing development is not only a built form, but a form that addresses a particular social class. Form follows the addressees. In architecture history, the addressee of housing developments is often overlooked, disguised or embellished; the form is often striped of its social meaning. In regard to this, the housing policy of dictatorships can be summarized as follows: urbanization of the middle classes, de-urbanization of unwanted classes. Thirdly, housing development of the interwar period was not static, but rather changing depending on the political, economic and societal changes. In particular, the world economic crisis had an immense influence on housing policy in democracies and dictatorships alike. Finally, the interwar period did not only produce low rise settlements. There was - not only in dictatorial regimes - the development of barracks. And there was also - predominantly in dictatorships - the development of urban housing that is still attractive today, but largely ignored in architectural historiography.

\footnotetext{
$1 \rightarrow$ In fact, this is equally true for the debate on public housing during the Weimar Republic in Germany.

$2 \rightarrow$ This article is based on research on public housing during the Mussolini regime. Cf. Bodenschatz, H. (ed.) (2011). Städtebau für Mussolini. Auf der Suche nach der neuen Stadt im faschistischen Italien. Berlin: DOM publishers; Bodenschatz, H. (2013). Städtebau für Mussolini. Auf dem Weg zu einer neuen Rom. Berlin: DOM publishers. Cf. also: Benedetti, S., \& Cavallari, P. (2005). Qualità architettonica e qualità urbana nell'edilizia borghese e popolare a Roma (1890-1930). Roma: Regione Lazio, Direzione regionale piani e programmi di edilizia residenziale; Cocchioni, C., \& De Grassi, M. (1984). La casa popolare a Roma. Trent'anni di attività dell'I.C.P.. Roma: Edizioni Kappa; IED edizione; Fraticelli, V. (1982). Roma 1914-1929. La città e gli architetti tra la guerra e il fascismo. Roma: Officina; Masini, E. (2009). Piazza Bologna. Alle origini di un quartiere "borghese". Milano: FrancoAngeli; Vanelli, V. (1981). Economia dell'architettura in Roma fascista. Il centro urbano. Roma: Kappa; Villani, L. (2012). Le borgate del fascismo. Storia urbana, politica e sociale della periferia romana. Milano: Università di Torino. $3 \rightarrow$ Insolera, I. (1976). Roma moderna. Un secolo di storia urbanistica. Torino: Einaudi. pp 139-140.
} 